\title{
Growth Hormone Normalizes Low-Density Lipoprotein Receptor Gene Expression in Hypothyroid Rats
}

\author{
Nicoline Hoogerbrugge, Hans Jansen, Bart Staels, Lianne T. Kloet, and Jan C. Birkenhäger
}

\begin{abstract}
Hypothyroidism leads to a decreased activity of the low-density lipoprotein (LDL) receptor, which contributes to the hypercholesterolemia frequently seen during hypothyroidism. It is not known whether the decreased activity of the LDL receptor is directly due to the absence of thyroid hormone, or secondary to a deficiency of growth hormone (GH). Therefore, the effect of GH administration on LDL receptor activity was studied in hypothyroid rats. Following induction of hypothyroidism, the level of LDL receptor mRNA was significantly decreased in liver homogenates to $31 \% \pm 6 \%$ of the control value. LDL binding to liver cell membranes and plasma membranes decreased during hypothyroidism to approximately $65 \%$ of the control value. The effect of hypothyroidism on the hepatic LDL receptor was reflected in a significantly increased half-life of ${ }^{125}$-LDL of 29 hours in controls versus 48 hours in hypothyroid rats. Treatment of hypothyroid rats with human $\mathrm{GH}$ (hGH) resulted in normalization of both the amount of hepatic LDL receptor mRNA and LDL binding on liver cell membranes. The plasma half-life of human ${ }^{125}$-labeled LDL decreased during $\mathrm{GH}$ substitution but did not normalize. GH treatment significantly reduced plasma LDL cholesterol levels by $36 \%(P<.05, n=8)$, to levels that were still higher than in control animals. These data indicate that at least part of the decreased LDL receptor activity during hypothyroidism is secondary to GH deficiency.
\end{abstract}

Copyright 1996 by W.B. Saunders Company

$\mathbf{T}$ HE REGULATION OF plasma cholesterol concentration is multifactorial, with age, diet, and hormones playing major roles. Hypercholesterolemia is generally observed in patients with primary hypothyroidism. ${ }^{1-4}$ This hypercholesterolemia is caused by an increase in lowdensity lipoprotein (LDL) cholesterol concentration due to a reduced LDL receptor activity. $5,6 \mathrm{LDL}$ receptor activity in the hypothyroid state normalizes during substitution with thyroid hormone. ${ }^{7}$ This suggests that thyroid hormone stimulates the activity of the LDL receptor. However, thyroid hormone is also essential for the production of growth hormone $(\mathrm{GH})$. Reduction of $\mathrm{GH}$ is shown in patients with hypothyroidism. ${ }^{89}$ Therefore, substitution with thyroid hormone will normalize the activity of not only thyroid hormone but also GH. It has been shown that GH has a profound but not completely understood effect on cholesterol metabolism: in hypercholesterolemic adults, supraphysiological doses of GH decrease serum cholesterol, ${ }^{10}$ whereas GH overproduction (as found in acromegaly) is accompanied by low serum cholesterol levels. ${ }^{11}$ In addition, plasma LDL cholesterol concentration in hypothyroid patients shows a negative correlation to the activity of $\mathrm{GH}$, reflected in the concentration of plasma insulin-like growth factor-I (IGF-I). ${ }^{12}$ Substitution of hypophysectomized rats with GH decreases plasma LDL cholesterol. ${ }^{13,14}$ The increase in LDL receptor activity seen after substitution with thyroid hormone can be either a direct effect of thyroid hormone itself or an indirect effect via an increase in GH. ${ }^{8,15}$ In the present study, the effect of GH on LDL receptor activity was determined in hypothyroid rats.

From the Department of Internal Medicine III, University Hospital Dijkzigt, Rotterdam, The Netherlands.

Submitted February 15, 1994; accepted November 13, 1995.

Address reprint requests to Nicoline Hoogerbrugge, MD, Department of Internal Medicine III, University Hospital Dijkzigt, Dr. Molewaterplein 40,3015 GD Rotterdam, The Netherlands.

Copyright $\mathbb{}(1996$ by W.B. Saunders Company

0026-0495/96/4506-0003\$03.0010

\section{MATERIALS AND METHODS}

\section{Materials}

Human GH ([hGH] Norditropin) was a generous gift from Novo-Nordisk (Gentofte, Denmark). Chow was obtained from Puyk Diervoeders (Zutphen, The Netherlands); 2-mercapto-1-methylimidazole was from Janssen Chimica (Beerse, Belgium); the test kit combination, leupeptine and $\beta$-octyl glucoside, was from Boehringer (Mannheim, Germany); the IGF-I test kit was from Nichols Institute Diagnostics (San Juan Capistrano, CA); and x-ray films were from Kodak (Badhoevendorp, The Netherlands).

\section{Animals and Animal Treatment}

Male Wistar rats weighing $220 \pm 10 \mathrm{~g}$ were used. They were housed at $21^{\circ} \mathrm{C}$ on a 12 -hour light cycle. To avoid any intake of thyroid hormone, the animals were fed a vegetarian diet containing a mixture of grains, herbs, and seeds. Chow and drinking water were available ad libitum. Hypothyroidism was induced by addition of $0.05 \%$ (wt/vol) 2-mercapto-1-methyl-imidazole to the drinking water, resulting in thyroxine levels less than $1 \mathrm{nmol} / \mathrm{L}$ in all animals after 14 days of treatment. hGH was administered subcutaneously for 10 days twice daily in a daily physiological dose of $0.2 \mathrm{IU} / 100 \mathrm{~g}$ body weight dissolved in $0.1 \mathrm{~mL} 0.9 \% \mathrm{NaCl}^{16,17}$ Control animals were injected twice daily with $0.9 \% \mathrm{NaCl}$. On day 10 of substitution treatment, animals were killed after an overnight fast. Blood was collected in EDTA-containing tubes on ice. Livers were rinsed with $0.9 \% \mathrm{NaCl}$ and used immediately for determination of LDL receptor activity or frozen in liquid nitrogen and stored at $-80^{\circ} \mathrm{C}$ for mRNA analysis.

\section{Methods}

Total serum cholesterol, rat LDL, rat high-density lipoprotein (HDL), and triglycerides were determined as described previously. ${ }^{14}$ Rat LDL ( $\mathrm{d}=1.019$ to $\left.1.050 \mathrm{~g} / \mathrm{mL}\right)$ and rat HDL $(\mathrm{d}=1.050$ to $1.121 \mathrm{~g} / \mathrm{mL}$ ) were separated by ultracentrifugation for 24 hours at 200,000 $\times \mathrm{g}$ using an SW 41 rotor in a Beckmann L5-50 ultracentrifuge (Munchen, Germany) and isolated by tube-slicing. IGF-I concentration was determined by radioimmunoassay using a test kit. Rat GH was determined using a double-antibody radioimmunoassay as previously described ${ }^{18}$

Isolation and labeling of LDL. Human LDL was purified by ultracentrifugation $(\mathrm{d}=1.019$ to $1.063 \mathrm{~g} / \mathrm{mL})$ from fresh plasma of healthy donors. ${ }^{19} \mathrm{LDL}$ was labeled with ${ }^{125} \mathrm{I}$ as previously described 
(specific activity, 100 to $150 \mathrm{cpm} / \mathrm{ng}$ LDL protein). ${ }^{20,21}$ The iodinated LDL was used within 4 weeks. The free-iodine fraction of ${ }^{125}$ I-labeled LDL samples was less than $1 \%$.

LDL clearance studies. One hundred micrograms ${ }^{125}$ I-LDL protein was injected intravenously into the dorsal vein of the penis. At various times after injection, tail-tip blood samples $(40 \mu \mathrm{L})$ were collected in heparinized microhematocrit tubes. The microtubes were centrifuged, and $20 \mu \mathrm{L}$ of the plasma fraction was mixed with $480 \mu \mathrm{L}$ Krebs-Ringer bicarbonate buffer containing 5\% bovine serum albumin and $500 \mu \mathrm{L} 10 \%$ trichloroacetic acid (TCA). Radioactivity was counted (total activity), and then these samples were centrifuged for 4 minutes in an Eppendorf centrifuge (Hamburg, Germany) at $14,000 \mathrm{rpm}$. Intact ${ }^{125}$ I-LDL was determined by subtracting the TCA-soluble fraction from the total radioactivity. Kinetic parameters for ${ }^{125} \mathrm{I}$-LDL turnover were analyzed according to the method described by Matthews. ${ }^{22}$ Initial levels of radioactivity in the plasma were adjusted to $100 \%$. The log-linear profiles were resolved, and the (log-)linear portion of the curve corresponding to a period from 21 to 71 hours was fitted to the best monoexponential regression curve by the least-square method. The slope of this curve was used to determine the half-life of ${ }^{125}$ I-LDL. The LDL production rate in steady state is equal to the absolute catabolic rate, and was calculated from the product of the fractional catabolic rate (FCR) and plasma LDL levels.

Determination of $L D L$ receptor activity. Microsomes, endoplasmic reticulum (ER), and plasma membranes were isolated from liver homogenates by differential centrifugation in $0.3 \mathrm{~mol} / \mathrm{L}$ sucrose, using a modification of the method described by Aronson and Touster. ${ }^{23}$ Four volumes of medium $(0.3 \mathrm{~mol} / \mathrm{L}$ sucrose, 10 $\mathrm{mmol} / \mathrm{L} \mathrm{EDTA}$, and $1 \mathrm{~mol} / \mathrm{L} 2$-mercaptoethanol, $\mathrm{pH} \mathrm{7.4)}$ were added per gram of liver. The homogenate was centrifuged for 5 minutes at $900 \times g$ in a SS 34 rotor. The supernatant was centrifuged three times: 10 minutes at $8,700 \times g$ (SS 34 rotor), 10 minutes at $18,000 \times g$ (SS 34 rotor), and finally 30 minutes at $200,000 \times g(50.2 \mathrm{Ti}$ rotor $)$. The pellet containing the microsomes was used for isolation of plasma membranes and ER by gradient ultracentrifugation: $1 \mathrm{~mL}$ of the pellet was homogenized in $1.5 \mathrm{~mL}$ $57 \%$ sucrose. This sample was overlayered with $3 \mathrm{~mL} 34 \%$ sucrose and with $1.5 \mathrm{~mL} 10 \%$ sucrose. The tubes were centrifuged for 2.5 hours at 49,000 rpm in a SW 50.1 Ti rotor. Between the layers with $34 \%$ and $10 \%$ sucrose, a white band (plasma membranes) and, below it, a red band (ER), appeared. The samples were obtained by tube-slicing. Purification of organelles was confirmed by determination of the marker enzymes, glucose-6-phosphatase and 5' nucleotidase for the ER and plasma membranes, respectively (plasma membranes showed 5 times higher 5'nucleotidase activity and only $60 \%$ of the glucose-6-phosphatase activity per milligram of protein as compared with ER).

LDL receptor activity was determined by a modification of a dot-blot assay as described by Maggi and Catapano. ${ }^{24}$ The isolated membrane fragments $(50 \mu \mathrm{L}$ ) were suspended in $50 \mu \mathrm{L}, 50-\mathrm{mmol} / \mathrm{L}$ Tris maleate, $\mathrm{pH} 6.5$, containing $2 \mathrm{mmol} / \mathrm{L} \mathrm{CaCl}, 1.5 \mathrm{mmol} / \mathrm{L}$ PMSF, $0.1 \mathrm{mmol} / \mathrm{L}$ leupeptin, and $40 \mathrm{mmol} / \mathrm{L} \beta$-octyl-glucoside. The suspension was sonicated, and the undissolved material was pelleted by centrifugation for 4 minutes at $10,000 \times g$. The supernatant containing the $\beta$-octyl-glucoside-soluble material was diluted with $10 \mathrm{mmol} / \mathrm{L}$ Tris hydrochloride ( $\mathrm{pH} \mathrm{8)}$ containing 50 $\mathrm{mmol} / \mathrm{L} \mathrm{NaCl}$ and $2 \mathrm{mmol} / \mathrm{L} \mathrm{CaCl}_{2}$ (buffer $\mathrm{B}$ ). One hundred microliters of the membrane suspension was applied to nitrocellulose membranes using a manifold apparatus (Bio-Rad, Richmond, CA). The amount of protein applied to the nitrocellulose varied between 5 and $30 \mu \mathrm{g}$. The wells were washed three times with buffer B $(250 \mu \mathrm{L})$. After blocking for 1 hour in buffer B containing $30 \mathrm{mg} / \mathrm{mL}$ bovine serum albumin, the nitrocellulose membrane was incubated in buffer $B$ for 16 hours at $4^{\circ} \mathrm{C}$ with labeled LDL (10 $\mu \mathrm{g} / \mathrm{mL}$ or as indicated) and then washed five times with buffer $\mathrm{B}$ and dried for autoradiography. Quantitative analysis of the spots was performed using a scanning densitometer. All measurements were made in duplicate. Specificity of binding was evaluated in several ways: the presence of a 20 -fold excess of unlabeled LDL, disodium EDTA $(30 \mathrm{mmol} / \mathrm{L})$, or heparin $(4 \mathrm{mg} / \mathrm{mL})$ in the incubation medium decreased binding of ${ }^{125}$ I-LDL below the level of detection.

$L D L$ receptor $m R N A$ determination. Preparation of RNA from the liver of individual animals and dot-blot hybridizations of total cellular RNA were performed as described previously. ${ }^{25,26} \mathrm{~A}$ BamHI restriction fragment of the human LDL receptor clone, pLDLR-3, corresponding to nucleotide position 1079 to 1450 , was used as a probe for LDL receptor mRNA determination. ${ }^{27} \mathrm{~A}$ chicken 3 actin probe was used as a control ${ }^{28}$ to normalize for effects of differences in the amount of mRNA blotting. Actin content did not change by treatment with methimazol or GH (data not shown). Filters were hybridized to $1.5 \times 10^{6} \mathrm{cpm} / \mathrm{mL}$ of each probe as previously described. ${ }^{26}$ Quantitative analysis on autoradiograms of dot-blot filters was performed by scanning densitometry in the linear range of film sensitivity.

\section{Statistical Methods}

The data are presented as the mean \pm SD. ANOVA was used for comparison between groups, followed by Bonferroni correction. Comparison of linear regression lines was also made using ANOVA.

\section{RESULTS}

Treatment of rats with methimazol to induce hypothyroidism led to serum thyroxine concentrations below the detection level of $1 \mathrm{nmol} / \mathrm{L}$. In hypothyroid rats, endogenous $\mathrm{GH}$ $(\mathrm{rGH})$ and IGF-I levels decreased significantly to $22 \%$ and $67 \%$ of control values, respectively. Body weight remained the same over the last 9 days of methimazol treatment (Table 1). Treatment of hypothyroid rats with hGH led to an increase in plasma IGF-I concentrations to control values, whereas rGH level decreased further. Hypothyroid GH-treated animals gained body weight, in contrast to the non-GH-treated hypothyroid rats (Table 1).

\section{LDL Receptor Activity In Vivo}

Hypothyroidism led to hypercholesterolemia, due to an increased concentration of both HDL and LDL cholesterol of $54 \%$ and $370 \%$, respectively, as compared with control levels (Table 2). LDL receptor activity in intact rats was studied following the decay of ${ }^{125}$ I-LDL. During hypothyroid-

Table 1. Characteristics of the Different Treatment Groups

\begin{tabular}{|c|c|c|c|c|}
\hline Group & $\begin{array}{c}\mathrm{T}_{4} \\
\text { (nmol/L) }\end{array}$ & $\begin{array}{c}\mathrm{rGH} \\
(\mathrm{ng} / \mathrm{mL})\end{array}$ & $\begin{array}{c}1 \mathrm{GF}-\mathrm{I} \\
(\mathrm{U} / \mathrm{mL})\end{array}$ & $\begin{array}{c}\text { BWG } \\
\text { (g/9 d) }\end{array}$ \\
\hline Control $(n=6)$ & $35 \pm 9^{*}$ & $29.9 \pm 15.7^{*}$ & $3.36 \pm 0.52^{*}$ & $34 \pm 8^{*}$ \\
\hline Hypothyroid $(n=6)$ & ND & $6.7 \pm 4.1$ & $2.25 \pm 0.19$ & $-1 \pm 4$ \\
\hline $\begin{array}{l}\text { Hypothyroid }+\mathrm{GH} \\
\quad(n=8)\end{array}$ & ND & $3.7 \pm 2$ & $3.64 \pm$ & $9=$ \\
\hline
\end{tabular}

Abbreviations: $T_{4}$, thyroxine; $8 W G$, body weight gain; $N D$, not detectable.

${ }^{*} P<.05 \vee$ hypothyroid rats. 
Table 2. Effects of GH Treatment on Plasma Lipid Concentrations (mmol/L) in Hypothyroid Rats

\begin{tabular}{|c|c|c|c|c|}
\hline \multirow[b]{2}{*}{ Group } & \multicolumn{3}{|c|}{ Cholesterol } & \multirow[b]{2}{*}{ Triglycerides } \\
\hline & Total & LDL & $\mathrm{HDL}$ & \\
\hline $\begin{array}{l}\text { Control } \\
\qquad(n=6)\end{array}$ & $2.31 \pm 0.21^{*}$ & $0.31 \pm 0.04^{*}$ & $1.52 \pm 0.12^{*}$ & $1.08 \pm 0.25^{*}$ \\
\hline $\begin{array}{l}\text { Hypothroid } \\
\qquad(n=6)\end{array}$ & $4.21 \pm 0.48$ & $1.46 \pm 0.11$ & $2.34 \pm 0.47$ & $0.55 \pm 0.13$ \\
\hline $\begin{array}{c}\text { Hypothyroid+ } \\
\text { GH }(n=8)\end{array}$ & $3.48 \pm 0.29^{*}$ & $0.93 \pm 0.24^{*}$ & $2.06 \pm 0.10$ & $0.65 \pm 0.20$ \\
\hline
\end{tabular}

$* P<.05 v$ hypothyroid rats.

ism, the half-life of plasma ${ }^{125} \mathrm{I}-\mathrm{LDL}$ increased significantly from 29 hours in controls to 48 hours in hypothyroid rats $(P<.05, \mathrm{n}=4)$. After treatment with hGH, the decay of ${ }^{125}$ I-LDL was increased, with a half-life of 41 hours. The decay curve of $\mathrm{GH}$-treated rats was significantly different from that of hypothyroid rats $(P<.05, \mathrm{n}=4)$, but the half-life was still significantly less than in controls (Fig 1). These changes in half-life were paralleled by changes in the FCR (Table 3). On the other hand, the LDL production rate was significantly higher in hypothyroid rats as compared with controls ( 21 and $10 \mu \mathrm{mol} / \mathrm{L} / \mathrm{h}$, respectively, $P<$ $.01, \mathrm{n}=4$; Table 3). After hGH treatment, the ACR was not changed as compared with the rate in untreated hypothyroid rats $(20 \mu \mathrm{mol} / \mathrm{L} / \mathrm{h}, \mathrm{n}=4$; Table 3$)$. In hypothyroid rats, the increased production and decreased LDL removal rate results in a largely increased plasma LDL cholesterol content (Table 2). During GH treatment, the LDL removal rate is partly restored but the production rate is unaffected, reflected in a small decrease in plasma LDL concentration $(P<.05, \mathrm{n}=8)$.

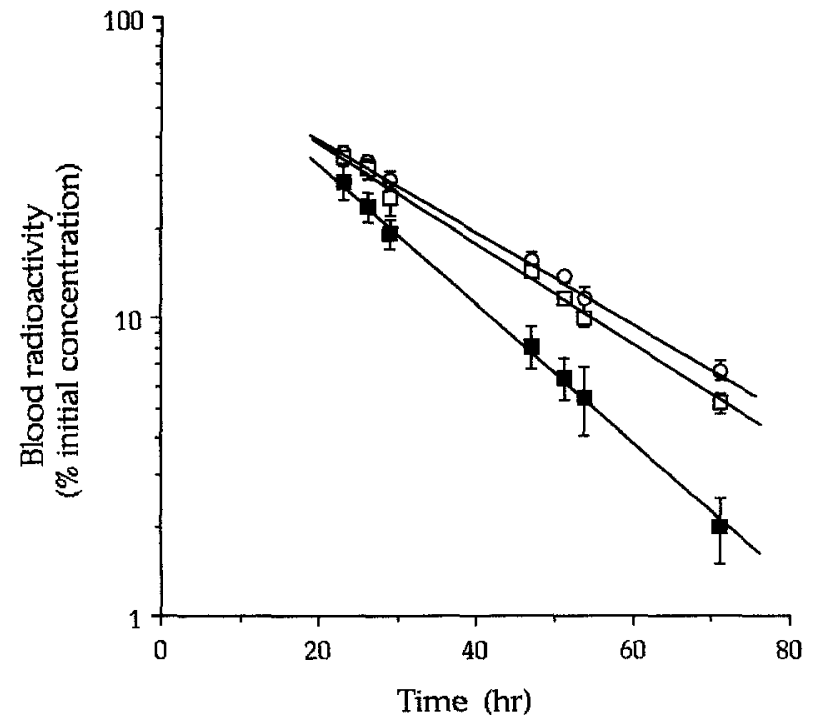

Fig 1. Plasma clearance of human $125 \mathrm{j}-\mathrm{LDL}$ in hypothyroid rats is significantly reduced as compared with controls $(P<.01)$. Substitution treatment of hypothyroid rats with $\mathrm{GH}$ increased the $\mathrm{LDL}$ clearance rate $(P<.05)$ but did not normalize it. Symbols represent the mean \pm SD. ( $\square$ ) Controls, ( $\square$ ) hypothyroid rats treated with $\mathrm{GH}$, and $(O)$ hypothyroid rats.
Table 3. Kinetic Parameters for ${ }^{125}$-LDL Turnover in Normal, Hypothyroid, and GH-Treated Hypothyroid Rats

\begin{tabular}{|c|c|c|c|}
\hline Group & Half-Life $(h)$ & FCR (pools/h) & $\begin{array}{c}\text { ACR } \\
(\mathrm{mmol} / \mathrm{h} / \mathrm{L} \text { plasma })\end{array}$ \\
\hline Control $(n=4)$ & $28.5 \pm 3.4$ & $0.028 \pm 0.005$ & $0.010 \pm 0.001$ \\
\hline Hypothyroid $(n=4)$ & $47.7 \pm 6.7^{*}$ & $0.017 \pm 0.003^{*}$ & $0.021 \pm 0.004^{*}$ \\
\hline $\begin{array}{l}\text { Hypothyroid + GH } \\
(n=4)\end{array}$ & $40.9 \pm 3.9^{*}$ & $0.020 \pm 0.002^{*}$ & $0.020 \pm 0.002^{*}$ \\
\hline
\end{tabular}

NOTE. The ACR is equal to the product of the FCR and plasma LDL levels. In steady state, the ACR is equal to the LDL production rate. Kinetic parameters were calculated as described by Matthews. ${ }^{22}$

Abbreviation: ACR, absolute catabolic rate.

$* P<.05 v$ control values.

\section{Hepatic LDL Receptor Activity In Vitro}

The effect of GH replacement on hepatic LDL receptor activity was studied using a ligand dot-blot assay. ${ }^{125}$ I-LDL was used as the ligand for binding to microsomal fractions isolated from control, hypothyroid, and hypothyroid GHtreated rats. With different amounts of microsomes containing between 5 and $15 \mu \mathrm{g}$ protein, specific LDL binding increased linearly with the amount of microsomes used (Fig 2). Microsomes isolated from hypothyroid rats contained, on a protein basis, the lowest LDL binding capacity. LDL binding to microsomes from control and GH-treated hypothyroid animals was similar. Optimal LDL binding occurred at LDL concentrations above $5 \mu \mathrm{g} / \mathrm{mL}$. Saturation curves with microsomes of control and GH-treated hypothyroid rats were similar, indicating that these microsomes contained the same number of LDL receptors with the same affinity for ${ }^{125} \mathrm{I}-\mathrm{LDL}$ (data not shown). To prove that the observed normalization in LDL binding after GH treatment in microsomes represented an increase in LDL receptor plasma membrane level, a plasma membrane-enriched fraction was isolated from the microsomes. ${ }^{125}$ I-LDL bound

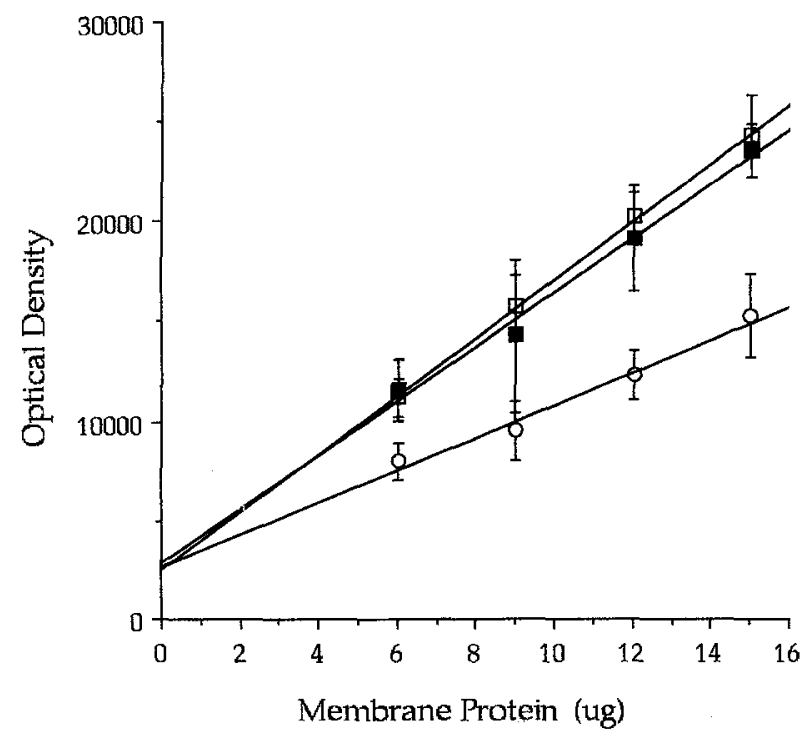

Fig 2. ${ }^{125}$-LDL binding to liver microsomes as a function of the concentration of membrane protein. Each point is the mean $\pm S D$ triplicate determinations. ( $\square$ ) Controls, ( $\square$ ) hypothyroid rats treated with $\mathrm{GH}$, and $(\mathrm{O})$ hypothyroid rats. 
to plasma membranes was $140 \% \pm 16 \%$ of the amount bound to the same amount of microsome protein. Using these plasma membranes in a dot-blot assay, it was shown that LDL binding capacity was completely restored by $\mathrm{GH}$ treatment (data not shown). These results show that GH treatment of hypothyroid rats leads to a normalization of the amount of LDL receptors in the liver.

\section{Hepatic LDL Receptor $m R N A$}

Hepatic LDL receptor mRNA levels were measured to determine the level at which the induction of LDL receptor activity by $\mathrm{GH}$ takes place. mRNA for the LDL receptor in hypothyroid rats was decreased to $31 \% \pm 6 \%$ of control level. GH treatment of hypothyroid rats led to a complete restoration of LDL mRNA levels to control values $(102 \% \pm 10 \%$; Fig 3$)$. These results suggested that GH may abolish the effects of hypothyroidism on the LDL receptor.

\section{DISCUSSION}

Plasma LDL cholesterol is increased during hypothyroidism. In hypothyroid rats, we found a diminished clearance rate of ${ }^{125}$ I-LDL and a decreased LDL binding capacity of the liver. The LDL receptor mRNA level was also diminished, suggesting that during hypothyroidism hypercholesterolemia is caused by reduced hepatic LDL receptor gene expression. This effect can be caused either by a deficiency of thyroid hormone or by the concomitant decrease in GH activity. We showed that GH substitution of hypothyroid rats resulted in a normalization both of $\mathrm{LDL}$ receptor mRNA and of LDL binding capacity in the liver. This indicates that LDL receptor activity is stimulated by $\mathrm{GH}$. However, plasma LDL cholesterol and the rate of LDL clearance did not normalize in GH-treated hypothyroid rats. A discrepancy existed between $\mathrm{GH}$ treatment effects on LDL receptor gene expression versus its effects on LDL cholesterol concentration.

The observed discrepancy may result from an enhanced LDL production rate in hypothyroidism, as shown previously. ${ }^{3}$ We confirmed this finding and showed that the increased production rate was not affected by the substitution of $\mathrm{GH}$. Another explanation can be found in a decreased membrane fluidity, which has been shown during hypothyroidism. ${ }^{29}$ The stiffer membranes might interfere with internalization or recycling of the LDL receptor. In such a situation, even a normal amount of LDL receptors can result in a less efficient catabolism. The lack of effect of GH on LDL cholesterol concentration could not be explained by nonfunctioning intracellular LDL receptors, since we showed that GH also normalized LDL receptor activity in isolated plasma membranes. The experimental model we used is different from the actual situation, since labeled human LDL was used in rats. Human LDL may not represent in vivo LDL clearance, since human LDL binds to the LDL receptor with a lower affinity than apo E-containing rat LDL. ${ }^{30,31}$. Therefore, human LDL has to compete with the apo E-containing endogenous rat LDL, which could result in an apparently lower clearance rate. However, human LDL was used both for binding studies and for the determination of clearance rate, and cannot explain the above-mentioned discrepancy. Moreover, it was shown by others that human ${ }^{125} \mathrm{I}-\mathrm{LDL}$ can be used as a model to study the LDL receptor, having important features in common with the binding of native LDL. ${ }^{32-34}$

Whatever the reason for the discrepancy between the LDL concentration and the hepatic LDL receptor activity, our results demonstrate unambiguously that $\mathrm{GH}$ affects

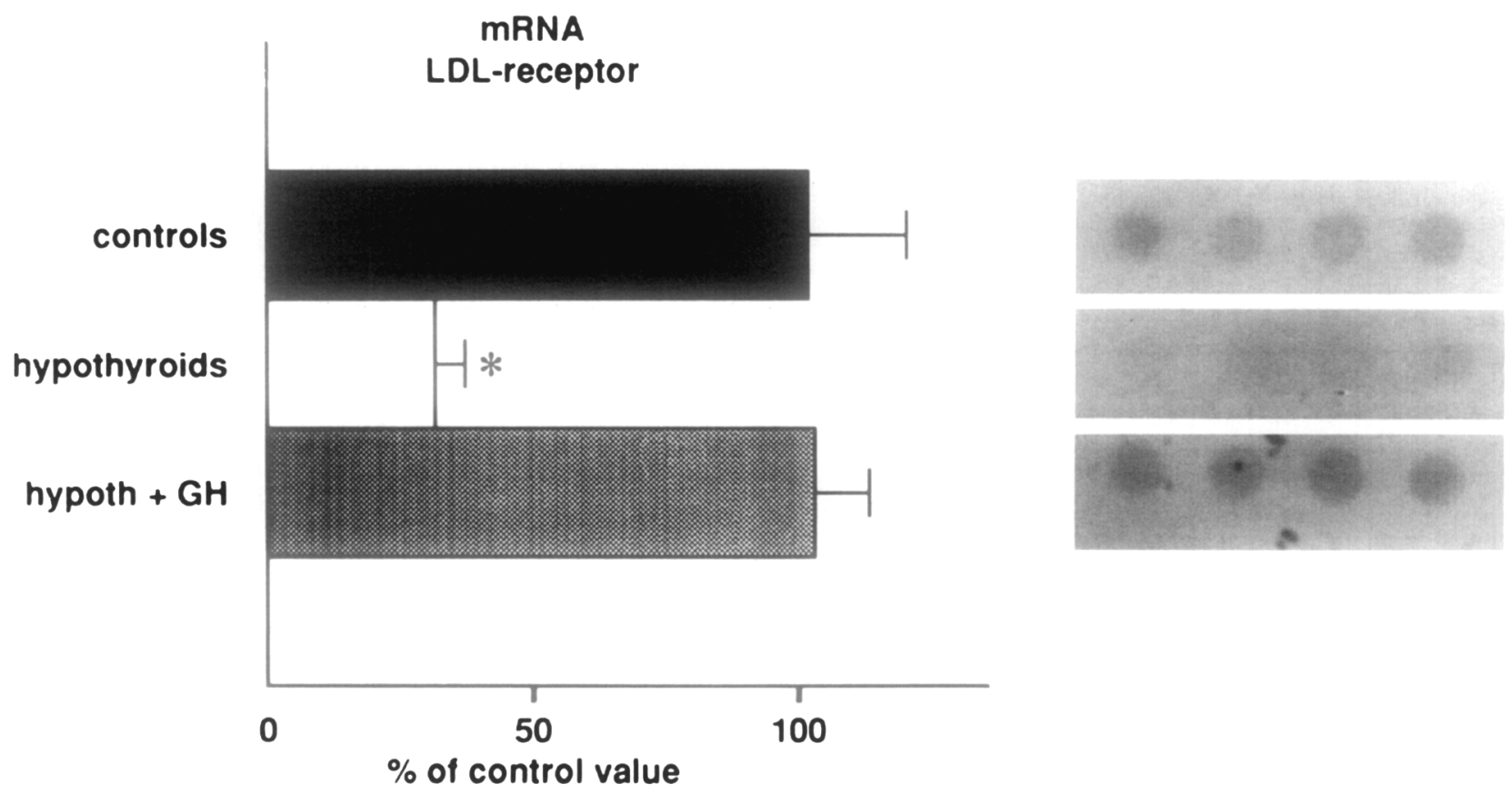

Fig 3. Effects of hypothyroidism and GH treatment of hypothyroid rats on mRNA for the LDL receptor for groups of 4 rats. Symbois represent the mean $\pm S D$. 
LDL receptor gene expression at the mRNA level: It can be concluded that at least part of the effect of hypothyroidism on LDL metabolism is due to the concomitant GH deficiency.

In the LDL receptor gene, a thyroid-responsive element has never been found, but it appeared to be present in the gene coding for GH. ${ }^{35}$ In hypophysectomized rats, with no GH production, it was shown by others that the hepatic LDL receptor mRNA level could only be elevated by very high doses of triiodothyronine. This mRNA level appeared to increase much slower than other well-known thyroid hormone-sensitive enzymes like $7 \alpha$-reductase. ${ }^{36}$ This suggests that thyroid hormone might activate the gene coding for $\mathrm{GH}$, resulting in $\mathrm{GH}$ activity, while $\mathrm{GH}$ affects the LDL receptor. Our results do not exclude a direct effect of thyroid hormone on LDL receptor activity. It has been shown that thyroid hormone has a stimulating effect on LDL catabolism. ${ }^{5-7}$ However, some of the cell culture experiments were performed in the presence of fetal calf serum (FCS) and may show the joint effect of thyroid hormone and GH. FCS contains some GH, but especially IGF-I in a sufficient concentration. We measured a GH concentration of approximately $0.2 \mu \mathrm{g} / \mathrm{L}$ and an IGF-I concentration between 7 and $36 \mathrm{nmol} / \mathrm{L}$, in FCS batches. Therefore, the contribution of thyroid hormone (or lack of it) to LDL cholesterol metabolism is difficult to assess from such experiments.

GH activity can be exerted by GH itself or via IGF-I. In our study with GH-treated hypothyroid rats, an increase in plasma IGF-I was shown, and endogenous rGH concentra- tion decreased further as compared with levels in hypothyroid rats. These data suggest that the stimulating effect of GH on LDL receptor activity may be mediated by IGF-I. Support for this theory has been found in patients with Laron-type dwarfism. Patients with Laron-type dwarfism are characterized by high plasma levels of $\mathrm{GH}$ and an inability to generate endogenous IGF-I, due to a GH receptor defect. In these patients, administration of IGF-I causes a decrease in plasma cholesterol concentration. ${ }^{37}$ Also, in healthy men, a decrease in cholesterol was shown after IGF-I injections. ${ }^{38}$ This suggests that the hypocholesterolemic effect of GH can be mediated by IGF-I.

The present study shows a stimulating role for $\mathrm{GH}$ in LDL metabolism. This contribution is relevant both for primary GH deficiency and for hypothyroidism. There is evidence now that $\mathrm{GH}$ may modulate hepatic responsiveness to the action of several other hormones, like thyroid hormone and estrogen. Recently, Rudling et al ${ }^{39}$ showed in estrogen-treated rats that $\mathrm{GH}$ was needed for the stimulating effect of estrogen on the LDL receptor. This permissive function of $\mathrm{GH}$ was also found in other components of lipid metabolism. In hypophysectomized rats, we have shown that hepatic lipase activity could only be stimulated by thyroid hormone during substitution of $\mathrm{GH} .{ }^{14}$

\section{ACKNOWLEDGMENT}

The authors thank M.J.E. Seip-deVries for excellent technical assistance and Dr S.W.J. Lamberts for determination of IGF-I, hGH, and rGH. hGH (Norditropin) was generously provided by Novo-Nordisk, Gentofte, Denmark.

\section{REFERENCES}

1. Walton KW, Scott PJ, Dykes PW, et al: The significance of alterations in serum lipids in thyroid dysfunction. Clin Sci 29:217238,1965

2. Dory L, Roheim PS: Rat plasma lipoproteins and apolipoproteins in experimental hypothyroidism. J Lipid Res 22:287-296, 1981

3. Sykes M, Cnoop-Koopmans WM, Julien P, et al: The effects of hypothyroidism, age and nutrition in the rat. Metabolism 30:733-738, 1981

4. Gross G, Syke M, Arellano R, et al: HDL clearance and receptor-mediated catabolism of $\mathrm{LDL}$ are reduced in hypothyroid rats. Atherosclerosis 66:269-275, 1987

5. Thompson GR, Soutar AK, Spengel FA, et al: Defects of receptor-mediated low density lipoprotein catabolism in homozygous familial hypercholesterolemia and hypothyroidism in vivo. Proc Natl Acad Sci USA 78:2591-2595, 1981

6. Scarabottola L, Trezzi E, Roma $P$, et al: Experimental hypothyroidism modulates the expression of the LDL-receptor by the liver. Atherosclerosis 59:329-333, 1986

7. Chait A, Bierman EL, Albers JJ: Regulatory role of triiodothyronine in the degradation of low density lipoprotein by cultured human skin fibroblasts. J Clin Endocrinol Metab 48:887-889, 1979

8. Katakami H, Down TR, Frohman L: Decreased hypothalamic growth hormone-releasing hormone content and pituitary responsiveness in hypothyroidism. J Clin Invest 77:11704-11711, 1986

9. Wood DF, Franklyn JA, Ramsden D, et al: The effect of thyroid hormones on growth hormone gene expression in vivo in rats. J Endocrinol 112:459-463, 1987

10. Friedman M, Byers SO, Rosenman RH, et al: Effect of subacute administration of human growth hormone on various serum lipid and hormone levels in hypercholesterolemic and normocholesterolemic subjects. Metabolism 23:905-912, 1974

11. Nikkilä EA, Pelkonen R: Serum lipids in acromegaly. Metabolism 24:829-838, 1975

12. Hoogerbrugge-van der Linden $\mathrm{N}$, Jansen $\mathrm{H}$, Hülsmann WC, et al: Relationship between insulin-like growth factor-I and lowdensity lipoprotein cholesterol levels in primary hypothyroidism in women. J Endocrinol 123:341-345, 1989

13. Byers SO, Friedman M, Rosenman RH: Prevention of hypercholesterolaemia in thyroidectomized rats by growth hormone. Nature 228:464-465, 1970

14. Hoogerbrugge-v.d. Linden N, Jansen H, Wouters NMH: Growth hormone and thyroxine affect lipoprotein metabolism in hypothyroid and hypophysectomized rats. J Endocrinol 125:403407,1990

15. Martin D, Epelbaum J, Bluet-Pajot M, et al: Thyroidectomy abolishes pulsatile growth hormone secretion without hypothalamic somatomedin. Neuroendocrinology 41:476-481, 1985

16. Jörgensen KD: Comparison of the pharmacological properties of pituitary and biosynthetic human growth hormone. Acta Endocrinol (Copenh) 114:24-131, 1987

17. Skottner A, Clark RG, Robinson ICAF, et al: Recombinant human insulin-like growth factor: testing the somatomedin hypothesis in hypophysectomized rats. J Endocrinol 112:123-132, 1987

18. Oosterom R, Verleun $T$, Zuyderwijk J, et al: Growth hormone secretion by cultured rat anterior pituitary cells. Effects of culture conditions and dexamethasone. Endocrinology 113:735741,1983

19. Zechner R, Meser R, Kostner GM: Isolation of pure LpB from human serum. J Lipid Res 27:681-686, 1986 
20. McFarlane AS: Labelling of plasma proteins with radioactive iodine. Biochem J 62:135-143, 1956

21. Billheimer DW, Eisenberg S, Levy R: The metabolism of very low density lipoprotein proteins. Biochim Biophys Acta 260:212-221, 1972

22. Matthews CEM: The theory of tracer experiments with ${ }^{131}$ I-labeled plasma proteins. Phys Med Biol 2:36-53, 1957

23. Aronson NN, Touster O: Isolation of rat liver plasma membrane fragments in isotonic sucrose. Methods Enzymol 31:90102,1974

24. Maggi FM, Catapano AL: A dot-blot assay for the low density lipoprotein receptor. J Lipid Res 28:108-112, 1987

25. Chirgin JM, Przybyla AE, MacDonald RJ, et al: Isolation of biologically active ribonucleic acid from sources enriched in ribonuclease. Biochemistry 18:5294-5297, 1979

26. Staels B, Auwerx J, Chan L, et al: Influence of development, oestrogens and food intake on apolipoprotein A-I, A-II and E mRNA in the rat liver and intestine. J Lipid Res 30:1137-1141, 1989

27. Staels B, van Tol A, Chan L, et al: Alterations in thyroid status modulate apolipoprotein, hepatic triglyceride-lipase and LDL-receptor in rats. Endocrinology 127:1144-1152, 1990

28. Cleveland DW, Lopata MA, MacDonald RJ, et al: Number and evolutionary conservation of alpha- and $\beta$-tubulin and cytoplasmic $\beta$ - and gamma-actin genes using specific cloned cDNA probes. Cell 20:958-962, 1980

29. Cooper RA: Abnormalities of cell-membrane fluidity in the pathogenesis of disease. N Engl J Med 297:371-377, 1977

30. Mahley RW, Weisgraber KH, Melchior GW, et al: Inhibition of receptor-mediated clearance of lysine and arginine modified lipoproteins from the plasma of rats and monkeys. Proc Natl Acad Sci USA 77:225-229, 1980
31. Hooft van FM, Tol van A: Sites of degradation of purified rat low density lipoprotein and high density lipoprotein in the rat. Biochim Biophys Acta 839:344-353, 1985

32. Goldstein JL, Basu SK, Brunschede GY, et al: Release of low density lipoprotein from its cell surface receptor of sulfated glucosaminoglycans. Cell 7:85-95, 1976

33. Harkes L, van Berkel THJC: Cellular localization of the receptor-dependent and receptor independent uptake of human LDL in liver of normal and 17 alpha-ethinyl estradiol treated rats. FEBS Lett 154:75-80, 1983

34. Salter AM, Bugaut M, Saxton $J$, et al: Effects of preincubation of primary monolayer cultures of rat hepatocytes with low- and high-density lipoproteins on subsequent binding and metabolism of human low-density lipoprotein. Biochem J 247:79-84, 1987

35. Glass CK, Holloway JM, Devary OV, et al: The thyroid hormone receptor binds with opposite transcriptional effects to a common sequence motif in thyroid hormone and estrogen response elements. Cell 54:313-323, 1988

36. Ness GC: Thyroid hormone. Basis for its hypocholesterolemic effect. J Fla Med 78:383-385, 1991

37. Laron Z, Klinger B, Jensen LT, et al: Biochemical and hormonal changes induced by one week administration of rIGF-I to patients with Laron type dwarfism. Clin Endocrinol (Oxf) $35: 145-150,1991$

38. Oscarsson, Lundstam U, Gustafsson B, et al: Recombinant human insulin-like growth factor-I decreases serum lipoprotein(a) concentrations in normal adult men. Clin Endocrinol (Oxf) 42:673676,1995

39. Rudling $\mathbf{M}$, Norstedt $\mathrm{G}$, Olivecrona $\mathbf{H}$, et al: Importance of growth hormone for induction of hepatic low density lipoprotein receptors. Proc Natl Acad Sci USA 1989:6983-6987, 1992 